Check for updates

Cite this: RSC Adv., 2017, 7, 48466

Received 29th September 2017 Accepted 9th October 2017

DOI: $10.1039 / c 7 r a 10768 d$

rsc.li/rsc-advances

\title{
Natural terpenoid glycosides with in vitro/vivo antithrombotic profiles from the leaves of Crataegus pinnatifida†
}

\author{
Pin-Yi Gao, ${ }^{\text {ab }}$ Ling-Zhi Li, ${ }^{\text {a }}$ Ke-Chun Liu, ${ }^{c}$ Chen Sun, ${ }^{c}$ Xue Sun, ${ }^{a}$ Ya-Nan Wu${ }^{a}$ \\ and Shao-Jiang Song (D) *a
}

Two norditerpenoids (1-2) with unique carbon skeletons, four sesquiterpenoids (3-6) and nine norsesquiterpenoids (7-15) were isolated from the leaves of Crataegus pinnatifida and evaluated as possessing antithrombotic activities in vitro/vivo. Their structures with absolute configurations were determined via a combination of spectroscopic data, chemical methods, and quantum-chemical calculations (ECD, NMR, and OR data). Compound 3 showed an inhibitory effect on ADP induced platelet aggregation in vitro, which is mediated through the response to the specific receptor of $\mathrm{P}_{2} \mathrm{Y}_{12}$ by docking results. Compound 3 also clearly prolonged the time to form thrombocytes induced by $\mathrm{FeCl}_{3}$, in the caudal vessels of zebrafish.

\section{Introduction}

Abnormal thrombosis is a key factor in serious cardiovascular diseases (CVDs) that are among the leading killers around the world. ${ }^{1}$ The majority of cardiovascular diseases, including acute coronary syndrome, ischemic stroke and peripheral vascular diseases, are associated with thrombotic disorders. ${ }^{2}$ Platelet activation in atherosclerotic arteries is central to the development of arterial thrombosis. Therefore, the inhibition of platelet aggregation must occur to prevent a thrombotic event. ${ }^{3}$ Current antithrombotic discovery efforts target compounds that have improved therapeutic indices compared to the standard of care. ${ }^{4}$ This fact has stimulated great interest in the search for natural bioactive compounds (NBC) from herbal drugs or herbal medicinal preparations that are highly efficacious in thrombin reduction while having minimal or reduced bleeding liabilities. ${ }^{2,5}$ Research on novel bioactives and drugs with different mechanisms of action and increased efficacy, and low toxicity is highly desired. The leaves of Crataegus pinnatifida (hawthorn leaves) have been used to treat cardiovascular disease for several

${ }^{a}$ Key Laboratory of Structure-Based Drug Design and Discovery, Ministry of Education, School of Traditional Chinese Materia Medica, Shenyang Pharmaceutical University, Shenyang 110016, People's Republic of China. E-mail: songsj99@163.com; lilingzhijessie@163.com

${ }^{b}$ College of Pharmaceutical and Biotechnology Engineering, Institute of Functional Molecules, Shenyang University of Chemical Technology, Shenyang 110142, People's Republic of China

'Biology Institute of Shandong Academy of Sciences, Jinan, People's Republic of China $\dagger$ Electronic supplementary information (ESI) available: NMR, HRESIMS, ECD and $\mathrm{Rh}_{2}\left(\mathrm{OCOCF}_{3}\right)_{4}$-ICD spectra of compounds; details of calculated and experimental ECD, ${ }^{13} \mathrm{C}$ NMR and ORs, MTPA esters, acid hydrolysis and in vitro and in vivo antithrombotic assays. See DOI: $10.1039 / \mathrm{c} 7 \mathrm{ra10768d}$ decades in Europe, China and the United States. ${ }^{6,7}$ An extract of hawthorn leaves, Yixintong medicinal preparations, is one of the most effective drugs available for blood-activating and stasis-dissolving. ${ }^{8,9}$ The flavonoids have been considered as the only effective component until terpenoids (monoterpenoid and sesquiterpenoid) with antithrombotic activity were obtained recently from the leaves of $C$. pinnatifida. ${ }^{10-13}$ As a new effective ingredient, the terpenoids exhibit potential antithrombotic activity both in vitro and in vivo. ${ }^{14}$

In continuing the search for antithrombotic agents, two novel norditerpenoids with unique carbon skeletons were isolated as the first diterpenoids from the leaves of the title plant, together with two new sesquiterpenoids $(3,4)$ and 11 known ones (5-15). The absolute configurations of 1-4 were determined by producing of $\mathrm{Rh}_{2}\left(\mathrm{OCOCF}_{3}\right)_{4}$ complexes or Mosher ester, and by comparison of ECD, NMR, and optical rotation (OR) data with the calculated values. In this report, the isolation, structure elucidation, and in vitro and in vivo antithrombotic evaluation of the isolates (Fig. 1) are described.

\section{Results and discussion}

The ethanol extract from the leaves of $C$. pinnatifida was separated and purified by macroporous resin, polyamide, silica gel, $\mathrm{C}_{18}$ reversed silica gel and semipreparative HPLC to afford two norditerpenoids (1-2), 13 sesquiterpenoids (3-15). The known compounds (5-15) were identified as shnyegenin B (5), ${ }^{12}$ shnyeside B (6), ${ }^{12}(3 S, 5 R, 6 R, 7 E, 9 S)$-megastiman-7-ene-3,5,6,9tetrol (7), ${ }^{12}$ euodionosides D $(8),{ }^{13}(6 R, 9 R)$-3-oxo- $\alpha$-ionol-9-O- $\beta$ D-glucopyranoside $\quad(9),{ }^{13} \quad(6 S, 7 E, 9 R)-6,9$-dihydroxy-4,7-megastiymadien-3-one-9-O-[ $\beta$-D-xylopyranosy- $\beta$-D-glucopyranoside] $(\mathbf{1 0}),{ }^{12} \quad$ linarionoside $\quad \mathrm{A} \quad(\mathbf{1 1}),{ }^{13} \quad$ linarionoside $\quad \mathrm{B} \quad(\mathbf{1 2}),{ }^{12}$ 

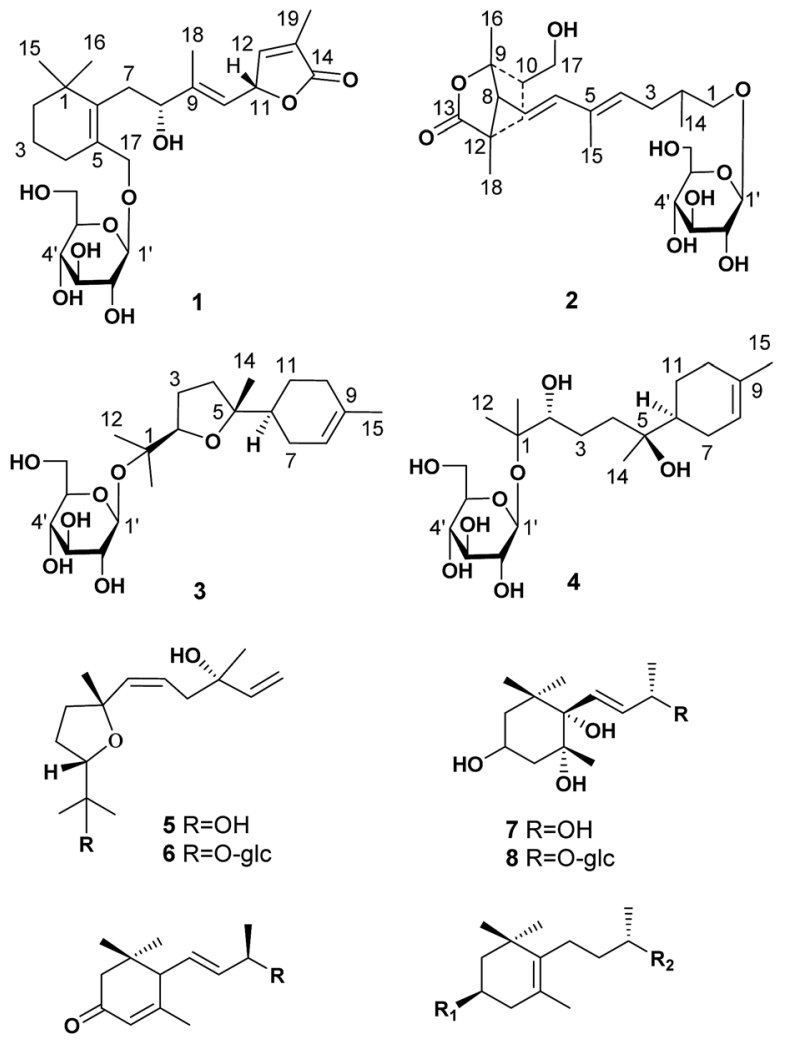

$9 \mathrm{R}=\mathrm{O}-\mathrm{glc}$ $10 \mathrm{R}=\mathrm{O}-\mathrm{glc}-\mathrm{xyl}$

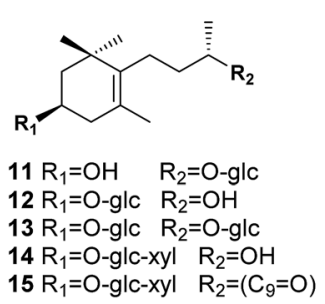

Fig. 1 The structures of compounds 1-15

linarionoside C (13), ${ }^{12}$ 3,9-dihydroxy-5-megastigmen-3- $O$-[ $\beta$-Dxylopyranosy- $\beta$-D-glucopyranoside] (14), ${ }^{12}$ pinnatifidanoside $\mathrm{C}$ $(\mathbf{1 5})^{\mathbf{1 4}}$ by comparison of their spectroscopic data with literature data (ESI-E.2. $\dagger$ ).

Compound 1, a colorless oil, was assigned the molecular formula of $\mathrm{C}_{25} \mathrm{H}_{38} \mathrm{O}_{9}$ as determined by the HRESIMS ion at $m / z$ 483.2582 $[\mathrm{M}+\mathrm{H}]^{+}$(calc. 483.2589). The ${ }^{1} \mathrm{H}$ NMR data (Table 1) showed the presence of four tertiary methyls at $\delta_{\mathrm{H}} 0.82(3 \mathrm{H}, \mathrm{s})$, $0.88(3 \mathrm{H}, \mathrm{s}), 1.57(3 \mathrm{H}, \mathrm{s})$ and $1.78(3 \mathrm{H}, \mathrm{s})$, a pair of oxygenated methylene protons at $\delta_{\mathrm{H}} 3.90(1 \mathrm{H}, \mathrm{d}, J=10.8 \mathrm{~Hz})$ and $4.48(1 \mathrm{H}$, $\mathrm{d}, J=10.8 \mathrm{~Hz})$, two oxygenated methine protons at $\delta_{\mathrm{H}} 3.80(1 \mathrm{H}$, $\mathrm{m})$ and $5.23(1 \mathrm{H}, \mathrm{d}, J=9.6 \mathrm{~Hz})$, and there were two olefinic $\mathrm{H}$ atoms which appeared to be at two double bonds separately $5.49(1 \mathrm{H}, \mathrm{d}, J=9.6 \mathrm{~Hz})$ and $7.26(1 \mathrm{H}, \mathrm{s})$. In addition, an anomeric proton signal appeared to be at $4.17(1 \mathrm{H}, \mathrm{d}, J=$ $7.5 \mathrm{~Hz}$ ), while six oxygenated $\mathrm{H}$-atoms at $\delta_{\mathrm{H}} 2.90-3.60$ indicated the presence of a sugar moiety. The ${ }^{13} \mathrm{C}$ NMR spectrum (Table 1 ) exhibited 25 carbon resonances, from which, four methyls $\left(\delta_{\mathrm{C}}\right.$ $10.9,14.7,28.1,28.2)$, four methylenes $\left(\delta_{\mathrm{C}} 21.0,31.0,41.0,45.2\right)$, a quaternary carbon $\left(\delta_{\mathrm{C}} 36.5\right)$, three carbons bearing oxygen $\left(\delta_{\mathrm{C}}\right.$ $67.0,70.7,84.9)$, three double bond groups $\left(\delta_{\mathrm{C}} 124.2,128.6\right.$, $132.1,138.6,140.8,151.7)$, one ester carbonyl group $\left(\delta_{\mathrm{C}} 174.5\right)$, and a sugar group $\left(\delta_{\mathrm{C}} 61.9,70.8,74.2,77.6,77.6\right.$ and 103.6) were identified, which suggested that compound $\mathbf{1}$ is a norditerpene glycoside. Further information about the 2D structure of 1 was
Table $1{ }^{1} \mathrm{H}$ and ${ }^{13} \mathrm{C}$ NMR date of compounds 1 and 2 (DMSO- $d_{6}$ )

\begin{tabular}{|c|c|c|c|c|c|c|}
\hline \multirow[b]{2}{*}{ Position } & \multicolumn{3}{|l|}{$1^{a}$} & \multicolumn{3}{|l|}{$2^{a}$} \\
\hline & $\delta_{\mathrm{C}}$ & Type & $\begin{array}{l}\delta_{\mathrm{H}}, \text { mult. } \\
(J \text { in } \mathrm{Hz})\end{array}$ & $\delta_{\mathrm{C}}$ & Type & $\begin{array}{l}\delta_{\mathrm{H}}, \text { mult. } \\
(J \text { in } \mathrm{Hz})\end{array}$ \\
\hline 1 & 36.5 & $\mathrm{C}$ & & 75.3 & $\mathrm{CH}_{2}$ & $3.65 \mathrm{~m}$ \\
\hline 2 & 41.0 & $\mathrm{CH}_{2}$ & $\begin{array}{l}\text { a } 1.30 \mathrm{~m} \\
\text { b } 1.40 \mathrm{~m}\end{array}$ & 37.1 & $\mathrm{CH}$ & $1.52 \mathrm{~m}$ \\
\hline 3 & 21.0 & $\mathrm{CH}_{2}$ & $1.54 \mathrm{~m}$ & 24.0 & $\mathrm{CH}_{2}$ & $\begin{array}{l}\text { a } 1.55 \mathrm{~m} \\
\text { b } 2.19 \mathrm{~m}\end{array}$ \\
\hline 4 & 31.0 & $\mathrm{CH}_{2}$ & $\begin{array}{l}\text { a } 2.04 \mathrm{~m} \\
\text { b } 2.30 \mathrm{~m}\end{array}$ & 134.4 & $\mathrm{CH}$ & $5.54 \mathrm{~m}$ \\
\hline 5 & 132.1 & $\mathrm{C}$ & & 133.6 & $\mathrm{C}$ & \\
\hline 6 & 140.8 & $\mathrm{C}$ & & 141.7 & $\mathrm{CH}$ & $6.28 \mathrm{~d}(15.3)$ \\
\hline 7 & 45.2 & $\mathrm{CH}_{2}$ & $2.89 \mathrm{~m}$ & 118.8 & $\mathrm{CH}$ & $5.54 \mathrm{~m}$ \\
\hline 8 & 67.0 & $\mathrm{CH}$ & $3.80 \mathrm{~m}$ & 58.2 & $\mathrm{CH}$ & $2.48 \mathrm{~m}$ \\
\hline 9 & 138.6 & $\mathrm{C}$ & & 86.0 & $\mathrm{C}$ & \\
\hline 10 & 124.2 & $\mathrm{CH}$ & $5.49 \mathrm{~d}(9.6)$ & 38.6 & $\mathrm{CH}$ & $1.96 \mathrm{~m}$ \\
\hline 11 & 84.9 & $\mathrm{CH}$ & $5.23 \mathrm{~d}(9.6)$ & 37.1 & $\mathrm{CH}_{2}$ & $\begin{array}{l}\text { a } 1.45 \mathrm{~m} \\
\text { b } 1.57 \mathrm{~m}\end{array}$ \\
\hline 12 & 151.7 & $\mathrm{CH}$ & $7.26 \mathrm{~s}$ & 46.7 & $\mathrm{C}$ & \\
\hline 13 & 128.6 & $\mathrm{C}$ & & 179.5 & $\mathrm{C}$ & \\
\hline 14 & 174.5 & $\mathrm{C}$ & & 22.5 & $\mathrm{CH}_{3}$ & $1.16 \mathrm{~d}(6.0)$ \\
\hline 15 & 28.2 & $\mathrm{CH}_{3}$ & $0.82 \mathrm{~s}$ & 12.7 & $\mathrm{CH}_{3}$ & $1.75 \mathrm{~s}$ \\
\hline 16 & 28.1 & $\mathrm{CH}_{3}$ & $0.88 \mathrm{~s}$ & 23.8 & $\mathrm{CH}_{3}$ & $1.25 \mathrm{~s}$ \\
\hline 17 & 70.7 & $\mathrm{CH}_{2}$ & $\begin{array}{l}\text { a } 3.90 \mathrm{~d}(10.8) \\
\text { b } 4.48 \mathrm{~d}(10.8)\end{array}$ & 64.6 & $\mathrm{CH}_{2}$ & $3.51 \mathrm{~m}$ \\
\hline 18 & 14.7 & $\mathrm{CH}_{3}$ & $1.57 \mathrm{~s}$ & 19.5 & $\mathrm{CH}_{3}$ & $0.94 \mathrm{~s}$ \\
\hline 19 & 10.9 & $\mathrm{CH}_{3}$ & $1.78 \mathrm{~s}$ & & & \\
\hline $1^{\prime}$ & 103.6 & $\mathrm{CH}$ & $4.17 \mathrm{~d}(7.5)$ & 103.4 & $\mathrm{CH}$ & $4.16 \mathrm{~d}(7.8)$ \\
\hline $2^{\prime}$ & 74.2 & $\mathrm{CH}$ & $2.90 \mathrm{~m}$ & 74.3 & $\mathrm{CH}$ & $2.92 \mathrm{~m}$ \\
\hline $3^{\prime}$ & 77.6 & $\mathrm{CH}$ & $3.11 \mathrm{~m}$ & 77.5 & $\mathrm{CH}$ & $3.12 \mathrm{~m}$ \\
\hline $4^{\prime}$ & 70.8 & $\mathrm{CH}$ & $3.08 \mathrm{~m}$ & 70.8 & $\mathrm{CH}$ & $3.09 \mathrm{~m}$ \\
\hline $5^{\prime}$ & 77.6 & $\mathrm{CH}$ & $3.10 \mathrm{~m}$ & 77.5 & $\mathrm{CH}$ & $3.10 \mathrm{~m}$ \\
\hline $6^{\prime}$ & 61.9 & $\mathrm{CH}_{2}$ & $\begin{array}{l}\text { a } 3.33 \mathrm{~m} \\
\text { b } 3.60 \mathrm{~m}\end{array}$ & 61.9 & $\mathrm{CH}_{2}$ & $\begin{array}{l}\text { a } 3.33 \mathrm{~m} \\
\text { b } 3.60 \mathrm{~m}\end{array}$ \\
\hline
\end{tabular}

${ }^{a}$ Measured at $150 \mathrm{MHz}$ for ${ }^{13} \mathrm{C}$ in DMSO- $d_{6}$, and measured in $600 \mathrm{MHz}$ for ${ }^{1} \mathrm{H}$ in DMSO- $d_{6}$, (s) singlet, (d) doublet, (m) multiplet.

obtained from an HMBC experiment. The key correlations of $\mathbf{1}$ (Fig. 2), $\delta_{\mathrm{H}} 1.78(19-\mathrm{Me}) / \delta_{\mathrm{C}} 151.7$ (C-12), 128.6 (C-13), 174.5 (C14), $\delta_{\mathrm{H}} 5.23(\mathrm{H}-11) / \delta_{\mathrm{C}} 124.2(\mathrm{C}-10), 151.7(\mathrm{C}-12), 128.6(\mathrm{C}-13)$ and $\delta_{\mathrm{H}} 7.26(\mathrm{H}-12) / \delta_{\mathrm{C}} 84.9(\mathrm{C}-11), 128.6(\mathrm{C}-13), 174.5(\mathrm{C}-14)$, 10.9 (C-19), suggested the presence of an $\alpha, \beta$ unsaturated lactone. The other key correlations of 1 around $\delta_{\mathrm{H}} 0.82(15-\mathrm{Me})$, 0.88 (16-Me), 3.90 and 4.48 (17- $\left.\mathrm{CH}_{2} \mathrm{OH}\right), 1.57$ (18-Me) coupling with above part suggested the presence of the $\mathrm{C}_{19}$-norditerpenoid skeleton. In addition, the glycosidic site was established by a HMBC correlation from $\mathrm{H}-1^{\prime}\left(\delta_{\mathrm{H}} 4.17\right)$ and $\mathrm{C}-17\left(\delta_{\mathrm{C}} 70.7\right)$. The geometry of the double bond at C-9 was assigned as $E$ on the basis of the upfield shift of the methyl carbon signal in the ${ }^{13} \mathrm{C}$ NMR, $\delta_{\mathrm{C}} 14.7$ for $\mathrm{C}-18,{ }^{15}$ which was confirmed by NOE correlations with $\mathrm{H}-8$ and $\mathrm{H}-10$, as well as $\mathrm{H}-11$ and $\mathrm{H}_{3}-18$ (Fig. 3).

The absolute configuration of the norditerpenoid genin $\left(\mathbf{1}^{\prime}\right)$ obtained from acid hydrolysis of $\mathbf{1}$, was established by calculations of its ECD data, ${ }^{16,17}$ and the Bulkiness Rule for $\mathrm{Rh}_{2}(-$ $\left.\mathrm{OCOCF}_{3}\right)_{4}$ complexes of a secondary alcohol. ${ }^{18,19}$ A conformational search (MMFFs force field) for $\mathbf{1}^{\prime} \mathbf{a}$ and its enantiomer $\mathbf{1}^{\prime} \mathbf{b}$ led to 12 conformers, respectively, followed by geometric optimization of each one. 

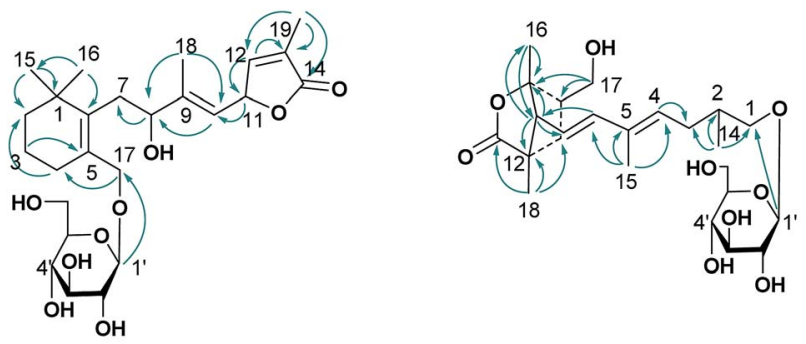

1
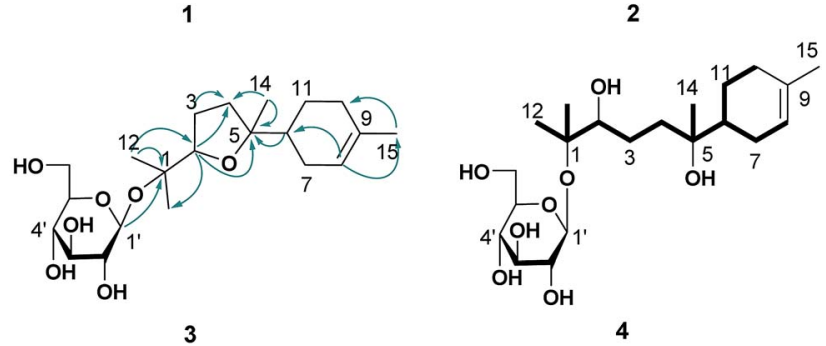

Fig. $2 \mathrm{HMBC}$ correlations (arrows) of $1-3$, and ${ }^{1} \mathrm{H}-{ }^{1} \mathrm{H}$ COSY (bold lines) of 4
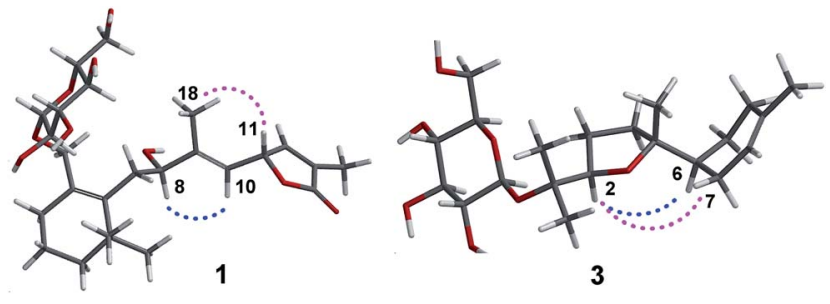

Fig. 3 Key NOESY correlations $(\mathrm{H}-\mathrm{H})$ of 1 and 3 .

The optimized conformers subjected to ECD calculations in $\mathrm{MeOH}$ (CPCM) using the B3LYP functional and the 6-311+G(d) basis set for TDDFT. The final calculated ECD was obtained as the result of the Boltzmann-weighted average. Comparison of the experimental ECD curve $\mathbf{1}^{\prime}$ and calculated ECD curves (Fig. 4) permitted the assignment of the absolute configuration of $\mathbf{1}^{\prime}$ as $8 R, 11 R$ (ESI-Table $\left.1 \dagger\right)$. In addition, the $\mathrm{Rh}_{2}\left(\mathrm{OCOCF}_{3}\right)_{4}{ }^{-}$ induced ECD experiment on the 8-OH of $\mathbf{1}^{\prime}$ also confirmed the above result (negative $\mathrm{E}$ band at $340 \mathrm{~nm}$ in spectra Fig. S24†). The D-glucose was identified by acid hydrolysis of $\mathbf{1}$ then comparison with an authentic sample by an HPLC analysis using OR detector (ESI-Fig. $3 \dagger$ ). Consequently, the structure of compound 1 was established and named norhawthornoid A.

Compound 2 was obtained as a colorless oil, and its HRESIMS exhibited a sodium adduct ion peak at $\mathrm{m} / \mathrm{z} 471.2588$ [M + $\mathrm{H}^{+}$(calc. 471.2589), corresponding to the molecular formula $\mathrm{C}_{24} \mathrm{H}_{38} \mathrm{O}_{9}$. In the ${ }^{1} \mathrm{H}$ NMR spectrum (Table 1 ) of 2 there were resonances attributable to four methyls at $\delta_{\mathrm{H}} 1.75(3 \mathrm{H}, \mathrm{s}), 1.25$ $(3 \mathrm{H}, \mathrm{s}), 0.94(3 \mathrm{H}, \mathrm{s})$ and $1.16(3 \mathrm{H}, \mathrm{d}, J=6.0 \mathrm{~Hz})$, two pair of oxygenated methylene protons at $\delta_{\mathrm{H}} 3.51(2 \mathrm{H}, \mathrm{m})$ and $3.65(2 \mathrm{H}$, $\mathrm{m})$, three olefinic $\mathrm{H}$-atoms at $\delta_{\mathrm{H}} 6.28(1 \mathrm{H}, \mathrm{d}, J=15.3 \mathrm{~Hz}), 5.54$ $(2 \mathrm{H}, \mathrm{m})$, an anomeric proton at $\delta_{\mathrm{H}} 4.16(1 \mathrm{H}, \mathrm{d}, J=7.8 \mathrm{~Hz})$, and six oxygenated $\mathrm{H}$-atoms at $\delta_{\mathrm{H}} 2.92-3.60$. The ${ }^{13} \mathrm{C}$ NMR spectrum (Table 1) exhibited 24 carbon resonances, from which, four
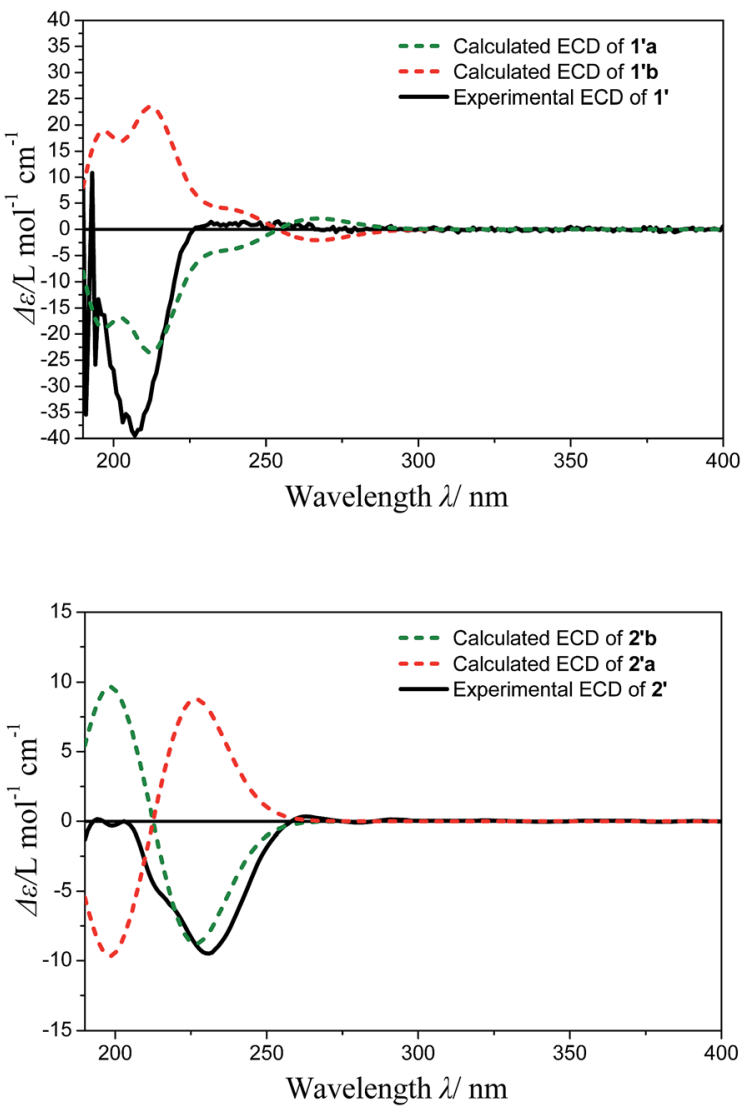

Fig. 4 Experimental and calculated ECD for 1 and 2.

methyls $\left(\delta_{\mathrm{C}} 12.7,19.5,22.5,23.8\right)$, two methylenes $\left(\delta_{\mathrm{C}} 24.0\right.$, $37.1)$, three methines $\left(\delta_{\mathrm{C}} 37.1,38.6,58.2\right)$, a quaternary carbon $\left(\delta_{\mathrm{C}} 46.7\right)$, four carbons bearing oxygen $\left(\delta_{\mathrm{C}} 64.6,75.3,86.0\right)$, two double bond groups $\left(\delta_{\mathrm{C}} 118.8,133.6,134.4,141.7\right)$, one ester carbonyl group $\left(\delta_{\mathrm{C}} 179.5\right)$, and a sugar group $\left(\delta_{\mathrm{C}} 61.9,70.8,74.3\right.$, $77.5,77.5$ and 103.4) were identified, which suggested that compound 2 has a norditerpenoid skeleton. Analysis of the ${ }^{1} \mathrm{H}$-, ${ }^{13} \mathrm{C}-\mathrm{NMR}$ and HSQC data helped us to assign $\mathrm{H}-$ to their bonded C-atoms (Table 1), and further information about the 2D structure of 2 (Fig. 2) was obtained from the HMBC experiment. The presence of bicyclic [2.2.1] rigid rings of 2 was supported by the long-range $\mathrm{HMBC}$ interactions $\delta_{\mathrm{H}} 1.25(16-\mathrm{Me}) / \delta_{\mathrm{C}} 58.2(\mathrm{C}-8)$, $86.0(\mathrm{C}-9), 38.6(\mathrm{C}-10) ; \delta_{\mathrm{H}} 3.51\left(17-\mathrm{CH}_{2} \mathrm{OH}\right) / \delta_{\mathrm{C}} 86.0(\mathrm{C}-9), 38.6(\mathrm{C}-$ $10), 37.1(\mathrm{C}-11) ; \delta_{\mathrm{H}} 0.94(18-\mathrm{Me}) / \delta_{\mathrm{C}} 58.2(\mathrm{C}-8), 37.1(\mathrm{C}-11), 46.7$ (C-12), 179.5 (C-13). The presence of the $\mathrm{C}_{9}$ side chain was established by other key correlations around $\delta_{\mathrm{H}} 1.16$ (14-Me), 1.75 (15-Me), 5.54 and 6.28 (olefinic $\mathrm{H}-4,6,7$ ). In addition, C-8 was assigned to the linkage site of above two moieties due to the key correlations between $\delta_{\mathrm{H}} 2.48(\mathrm{H}-8)$ and $\delta_{\mathrm{C}} 141.7(\mathrm{C}-6), 118.8$ (C-7), 86.0 (C-9), 37.1 (C-11), 46.7 (C-12), 23.8 (C-16), 19.5 (C-18). The location of the sugar moiety was determined by the HMBC correlations between $\mathrm{H}-1^{\prime}\left(\delta_{\mathrm{H}} 4.16\right)$ and $\mathrm{C}-1$ ( $\delta_{\mathrm{C}}$ 70.3) (Fig. 2). Furthermore, In the ${ }^{1} \mathrm{H}$ NMR data, the vicinal coupling constant $J_{(6,7)}$ of $15.3 \mathrm{~Hz}$ suggested a trans relationship between the protons H-6 and H-7. The geometry of the double bond at C-4 was assigned as $E$ on the basis of the upfield shift of the 
methyl carbon signal in the ${ }^{13} \mathrm{C}$ NMR spectrum $\left(\delta_{\mathrm{C}} 12.7\right.$ for C-15). ${ }^{15}$

The absolute configuration of the genin $2^{\prime}$ obtained from acid hydrolysis of 2 , was established by comparison of the experimental and calculated ECD and NMR data. ${ }^{16,17}$ The experimental ECD curves of $2^{\prime}$ (Fig. 4) matched well with the theoretically calculated ECD data of $\mathbf{2}^{\prime} \mathbf{b}$ using the TDDFT method at the B3LYP/6-311+G (d) level (ESI-Table $2 \dagger$ ). Thus, the absolute configuration of $2^{\prime}$ was determined to $8 R / 9 S / 10 R / 12 S$. Furthermore, the configuration of $\mathrm{C}-2$ was indicated by calculated NMR data. For this, our high-accuracy ${ }^{13} \mathrm{C}-\mathrm{NMR}$ calculation of the two possible stereoisomers $(2 R / 8 R / 9 S / 10 R / 12 S$ or $2 S /$ $8 R / 9 S / 10 R / 12 S$ ) indicated that the potential one is $2 S / 8 R / 9 S / 10 R /$ $12 S\left(R^{2}=0.9875\right.$, AveDev $\left.=3.5\right)$ (ESI-Fig. $\left.5 \dagger\right)$. Finally, the D configuration of the sugar moiety was determined by acid hydrolysis followed by an HPLC analysis with an authentic sample using an OR detector (ESI-Fig. $3 \dagger$ ). On the basis of the above evidence, the structure of 2 was determined and named norhawthornoid B.

Compound 3, a colorless oil, showed the molecular formula of $\mathrm{C}_{21} \mathrm{H}_{36} \mathrm{O}_{7}$ from the HRESIMS ion at $m / z 401.2536[\mathrm{M}+\mathrm{H}]^{+}$ (calc. 401.2534). The ${ }^{1} \mathrm{H}$ and ${ }^{13} \mathrm{C}$ NMR data (Table 2), assigned by HSQC and HMBC spectra, showed signals of four tertiary methyls at $\delta_{\mathrm{H}} 1.59(3 \mathrm{H}, \mathrm{s}), 1.16(3 \mathrm{H}, \mathrm{s}), 1.07(3 \mathrm{H}, \mathrm{s}), 1.02(3 \mathrm{H}, \mathrm{s})$, an oxygenated methine proton at $\delta_{\mathrm{H}} 3.82(1 \mathrm{H}, \mathrm{m})$, an olefinic proton at $\delta_{\mathrm{H}} 5.35(1 \mathrm{H}$, br s). Furthermore, an anomeric proton signal at $4.37(1 \mathrm{H}, \mathrm{d}, J=7.8 \mathrm{~Hz})$, and six oxygenated $\mathrm{H}$-atoms at $\delta_{\mathrm{H}}$ 2.86-3.62 indicated the presence of a sugar moiety. The ${ }^{13} \mathrm{C}$ NMR spectrum (Table 2) exhibited 21 carbon resonances, from which, four methyls $\left(\delta_{\mathrm{C}} 22.8,24.0,24.0,24.0\right)$, five methylenes $\left(\delta_{\mathrm{C}} 24.0,27.1,27.3,27.3,31.1\right)$, two methines $\left(\delta_{\mathrm{C}} 43.7,85.4\right)$, two quaternary carbons $\left(\delta_{\mathrm{C}} 78.4,85.2\right)$, a double bond group $\left(\delta_{\mathrm{C}}\right.$ $121.5,133.9)$, and a sugar group $\left(\delta_{\mathrm{C}} 61.9,71.1,74.4,77.2,77.8\right.$ and 98.0) were identified, which suggested that compound 3 is a sesquiterpenoid glycoside. In the HMBC spectrum (Fig. 2), the key correlations of 3 (Fig. 2), $\delta_{\mathrm{H}} 1.07$ (12-Me) $/ \delta_{\mathrm{C}} 78.4$ (C-1), 85.4 (C-2), $24.0(\mathrm{C}-13) ; \delta_{\mathrm{H}} 1.16(13-\mathrm{Me}) / \delta_{\mathrm{C}} 78.4$ (C-1), $85.4(\mathrm{C}-2), 22.8$ $(\mathrm{C}-12) ; \delta_{\mathrm{H}} 1.02(14-\mathrm{Me}) / \delta_{\mathrm{C}} 27.3(\mathrm{C}-4), 85.2(\mathrm{C}-5), 43.7$ (C-6), and $\delta_{\mathrm{H}} 1.59(15-\mathrm{Me}) / \delta_{\mathrm{C}} 121.5(\mathrm{C}-8), 133.9$ (C-9), 31.1 (C-10), suggested the presence of the bisabolane sesquiterpene skeleton. A longrange correlation between $\mathrm{H}-2\left(\delta_{\mathrm{H}} 3.82\right)$ and $\mathrm{C}-5\left(\delta_{\mathrm{C}} 85.2\right)$ suggested the presence of 2,5-ether moieties. In addition, the glycosidic site (C-1) was established unambiguously by an HMBC experiment, in which a long-range correlation between $\mathrm{H}-1^{\prime}\left(\delta_{\mathrm{H}} 4.37\right)$ and $\mathrm{C}-17\left(\delta_{\mathrm{C}} 78.4\right)$ was observed (Fig. 2). The relative configuration of 3 was determined by the key NOE correlations between $\mathrm{H}-2 / \mathrm{H}-6, \mathrm{H}-2 / \mathrm{H}_{2}-7$, which suggested that they were located on the same side of the tetrahydrofuran (THF) ring (C2-C5) (Fig. 3).

The absolute configuration of the sesquiterpene skeleton $\left(3^{\prime}\right)$ obtained by acid hydrolysis was established by comparison of the experimental and calculated OR. ${ }^{20}$ Due to the above NMR data, the configuration of $\mathbf{3}^{\prime}$ was identified as one of the two isomers $(2 R, 5 R, 6 S$ or $2 S, 5 S, 6 R)$. A conformational search using the MMFFs force field for the $(2 R, 5 R, 6 S)$-stereoisomer and its enantiomer led to the identification of 11 conformers, followed by geometric optimization of each one. The optimized conformers were subjected to OR calculations in $\mathrm{MeOH}$ (CPCM)

Table $2{ }^{1} \mathrm{H}$ and ${ }^{13} \mathrm{C}$ NMR date of compounds 3 and 4 (DMSO- $d_{6}$ )

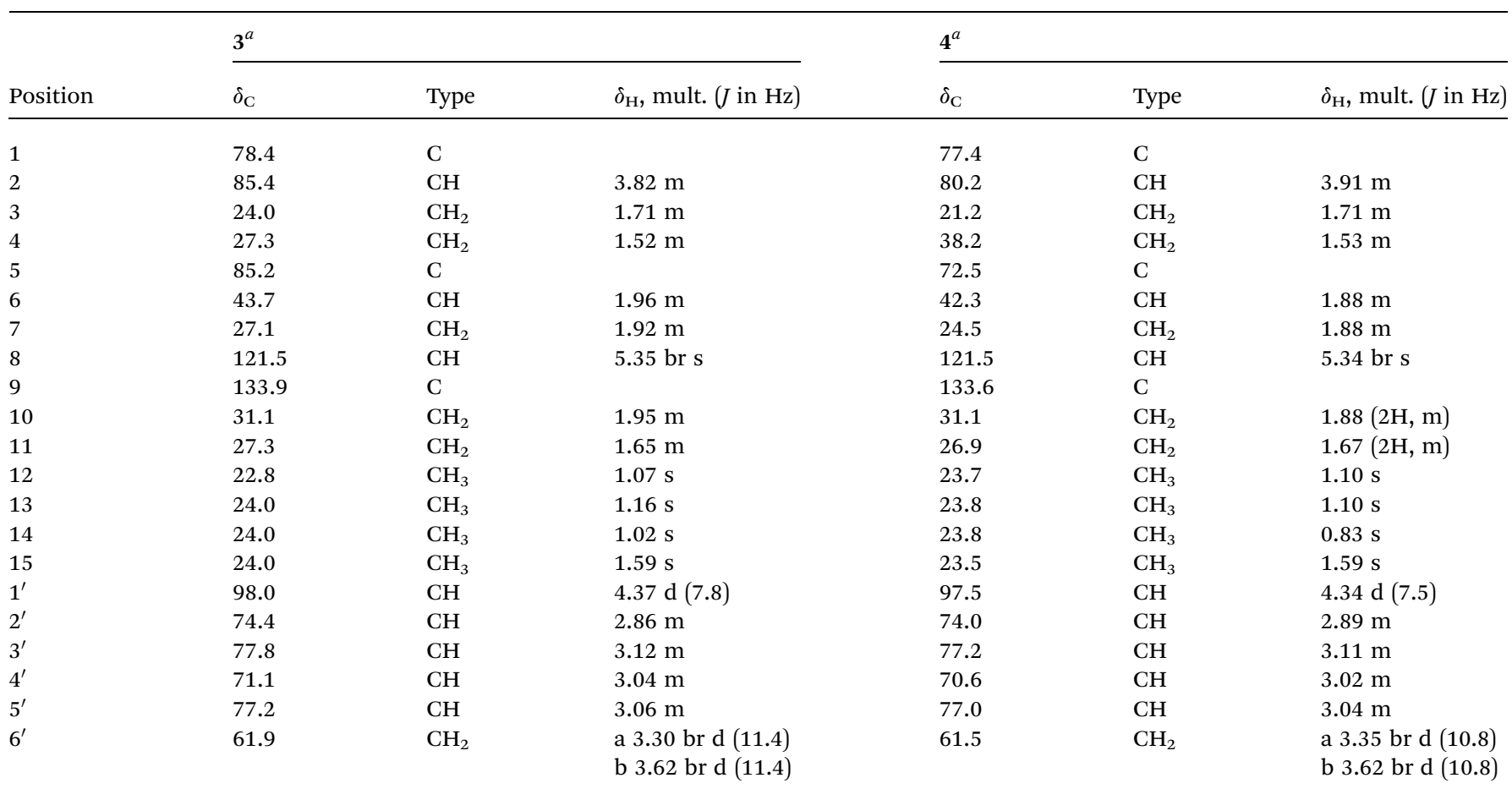

${ }^{a}$ Measured at $150 \mathrm{MHz}$ for ${ }^{13} \mathrm{C}$ in DMSO- $d_{6}$, and measured in $600 \mathrm{MHz}$ for ${ }^{1} \mathrm{H}$ in DMSO- $d_{6}$, (s) singlet, (d) doublet, (m) multiplet. 
using the B3LYP functional and the $6-311+G(d)$ basis set for DFT. Final calculated ORs were obtained as the result of the Boltzmann-weighted average (ESI-Table $6 \dagger$ ). From these results, the negative calculated ORs $\left([\alpha]_{20}^{\mathrm{D}}-8.7\right)$ of the $(2 R, 5 R, 6 S)$ stereoisomer was a better fit to the experimental OR value $\left([\alpha]_{20}^{\mathrm{D}}-2.8, c 0.4, \mathrm{MeOH}\right)$ than the positive one $\left([\alpha]_{20}^{\mathrm{D}}+8.7\right)$. In addition, the D-glucosyl moiety was confirmed by acid hydrolysis of $\mathbf{3}$ and then comparison with an authentic sample. Consequently, the structure of compound 3 was given the trivial name pinnatifidanoside $\mathrm{F}$.

Compound 4 was obtained as colorless oil and its molecular formula was determined as $\mathrm{C}_{21} \mathrm{H}_{38} \mathrm{O}_{8}$ by HRESIMS. In the ${ }^{1} \mathrm{H}$ NMR spectrum (Table 2), the presence of four tertiary methyls at $\delta_{\mathrm{H}} 1.59(3 \mathrm{H}, \mathrm{s}), 1.10(6 \mathrm{H}, \mathrm{s}), 0.83(3 \mathrm{H}, \mathrm{s})$, a oxygenated methine proton at $\delta_{\mathrm{H}} 3.91(1 \mathrm{H}, \mathrm{m})$, a olefinic proton at $\delta_{\mathrm{H}} 5.34(1 \mathrm{H}, \mathrm{br} \mathrm{s})$, were revealed, in addition, the anomeric proton signal at 4.34 $(1 \mathrm{H}, \mathrm{d}, J=7.5 \mathrm{~Hz})$ and six oxygenated $\mathrm{H}$-atoms at $\delta_{\mathrm{H}} 2.89-3.62$ demonstrated the presence of a saccharide group. The ${ }^{13} \mathrm{C}$ NMR spectrum (Table 2) exhibited 21 carbon resonances, from which, four methyls $\left(\delta_{\mathrm{C}} 23.5,23.7,23.8,23.8\right)$, five methylenes $\left(\delta_{\mathrm{C}} 21.2,24.5,26.9,31.1,38.2\right)$, two methines $\left(\delta_{\mathrm{C}} 42.3,80.2\right)$, two quaternary carbons $\left(\delta_{\mathrm{C}} 72.5,77.4\right)$, a double bond group $\left(\delta_{\mathrm{C}}\right.$ $121.5,133.6)$, and a sugar group $\left(\delta_{\mathrm{C}} 61.5,70.6,74.0,77.0,77.2\right.$ and 97.5) were identified, which suggested that compound 4 has a sesquiterpenoid skeleton closed to the structure of 3 . A careful comparison of the NMR spectroscopic data of 4 with that of 3 (Table 2) suggested that they have a closed sesquiterpenoid skeleton. Following analysis of their NMR data, the C2 and C5 atoms in 4 exhibiting -5.2 and $-\mathbf{1 2 . 7}$ ppm deviations respectively indicated that the THF ring was replaced by a 2,5-dihydroxy moiety, which was confirmed by HRESIMS data (Fig. 1). The multi-method combination of Mosher's method and comparison of the experimental and calculated NMR and OR values $^{\mathbf{2 1 - 2 3}}$ was presented here for support in the study of the absolute configuration of the sesquiterpene genin $\left(\mathbf{4}^{\prime}\right)$. Firstly, according to the MTPA shielding/deshielding effects of the two esters, the $\Delta \delta_{\mathrm{H}}(S-R)$ values (ESI-Fig. $\left.4 \dagger\right)$ revealed a $2 R$ configuration for $4^{\prime}$. Then, the configurations of C-5 and C-6 were indicated by calculated NMR and OR data. For this, our highaccuracy ${ }^{13} \mathrm{C}-\mathrm{NMR}$ calculation of the four possible stereoisomers $(2 R / 5 S / 6 S, 2 R / 5 S / 6 R, 2 R / 5 R / 6 S$ or $2 R / 5 R / 6 R)$ indicated that the potential one is $2 R / 5 S / 6 S\left(R^{2}=0.9980\right.$ larger than others) (Fig. 5, ESI-Fig. 6 and $7 \dagger)$. Meanwhile, the OR value of the $(2 R /$ $5 S / 6 S$ )-stereoisomer predicted to be -21.8 at the DFT level was in agreement with the experimental OR value $\left([\alpha]_{20}^{\mathrm{D}}-7.5, c 0.2\right.$, $\mathrm{MeOH})$. Furthermore, HPLC analysis of the acidic hydrolysate of 4 showed that the sugar moiety was a D-glucose. Thus, the structure of compound $\mathbf{4}$ was named pinnatifidanoside G.

The adenosine diphosphate (ADP), a granular content, act as agonists to activate more platelets and recruit them onto the subendothelial matrix, which contains cells, collagen, and von Willebrand factor, is exposed and tether to the site of injury. Our current study identified a key mechanism underlying antithrombotic effect of terpenoids from hawthorn leaves, showing that they blocked platelet activation by inhibiting the ADP pathway. ${ }^{14,24}$ In this study, all the isolates were tested in vitro for their antithrombotic effects by ADP induced platelet

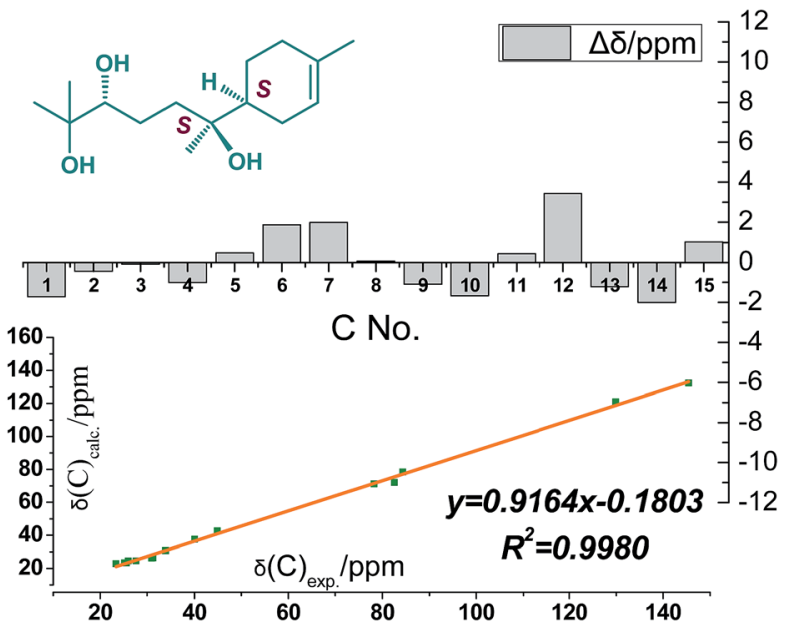

Fig. 5 Experimental and calculated ${ }^{13} \mathrm{C}$ chemical shifts of $4^{\prime} \mathrm{a}$.

aggregation experiment. ${ }^{25}$ The inhibitory activity of individual compounds is summarized in Table 3. Compounds 1-4, 8, 11 and 15 showed potent anti-platelet activities. Compound 3 a sesquiterpenoid displayed the best inhibitory activity in particular, inhibiting platelet aggregation by $84.00 \pm 4.00 \%$ at the final concentration of $0.25 \mathrm{mg} \mathrm{mL}^{-1}$ during the test interval. These results indicated that sesquiterpenoid inhibit platelet aggregations induced by ADP agonists, and thus it may have beneficial potential for the prevention of platelet-involved cardiovascular disease.

The $\mathrm{P} 2$ family of receptors mediates the platelet response to ADP, and mammalian platelets express three ADP subtypes receptors, namely, $\mathrm{P} 2 \mathrm{Y}_{1}, \mathrm{P}_{2} \mathrm{Y}_{12}$, and $\mathrm{P}_{2} \mathrm{X}_{1} \cdot{ }^{24,26}$ Among them, the $\mathrm{P}_{2} \mathrm{Y}_{12}$ receptor $\left(\mathrm{P} 2 \mathrm{Y}_{12} \mathrm{R}\right)$, a member of the $\mathrm{P} 2 \mathrm{Y}$ purinergic GPCR family stimulated by ADP, is one of the most important clinical drug targets for inhibition of platelet aggregation. ${ }^{26}$ Clopidogrel inhibits platelet activation through irreversible binding to the $\mathrm{P}_{2} \mathrm{Y}_{12}$ ADP receptor on platelet membrane. Therefore, compound 3, the most potent inhibitor of the ADP-induced platelet aggregation, was investigated as an antagonist of the direct-acting $\mathrm{P}_{2} \mathrm{Y}_{12}$ receptor by molecular modeling studies (Fig. 6). Also AZD1283 (the co-crystal ligand from crystal protein PDB code 4PXZ) was used as a positive control. ${ }^{26}$ These investigations indicate that (a) the $3^{\prime}-\mathrm{OH}$ and $1-\mathrm{O}-$ of 3 were in close

Table 3 Antiplatelet aggregation activity of compounds 1-15 ( $\bar{x} \pm \mathrm{SD}$, $n=3$ )

\begin{tabular}{llll}
\hline Samples & Inhibition rate $(\%)$ & Samples & Inhibition rate $(\%)$ \\
\hline $\mathbf{1}$ & $69.20 \pm 6.35$ & $\mathbf{9}$ & $<50$ \\
$\mathbf{2}$ & $74.00 \pm 4.50$ & $\mathbf{1 0}$ & $<50$ \\
$\mathbf{3}$ & $84.00 \pm 4.00$ & $\mathbf{1 1}$ & $68.25 \pm 1.35$ \\
$\mathbf{4}$ & $76.25 \pm 7.25$ & $\mathbf{1 2}$ & $64.55 \pm 1.75$ \\
$\mathbf{5}$ & $<50$ & $\mathbf{1 3}$ & $<50$ \\
$\mathbf{6}$ & $<50$ & $\mathbf{1 4}$ & $64.25 \pm 2.35$ \\
$\mathbf{7}$ & $54.05 \pm 5.25$ & $\mathbf{1 5}$ & $74.95 \pm 10.45$ \\
$\mathbf{8}$ & $76.95 \pm 2.45$ & & \\
Aspirin & $82.65 \pm 4.65$ & &
\end{tabular}




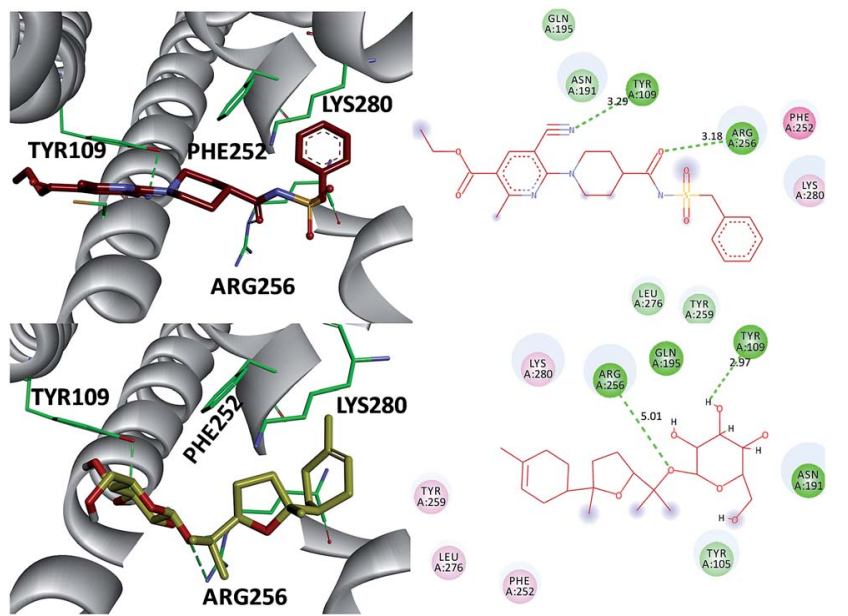

Fig. 6 Amino acids interacting with compound 3 and AZD1283. Hydrogen bonds are shown as green dots.

proximity to the catalytic residues Tyr 109 (2.97 ̊̊) and Arg 256 $(5.01 \AA)$ and underwent hydrogen bonding interactions. Also, the same hydrogen bonding interactions were oriented between AZD1283 and Tyr 109 and Arg 256 (distance 3.29 and $3.18 \AA$ ) (Fig. 7) (b) both AZD1283 and compound 3 were oriented in an aromatic pocket consisting of Tyr 109, Phe 252, Arg 256, and Lys 280. In addition, Tyr 105, Asn 191, Gln 195, Tyr 259, and Leu 276 are also considered as key active residues interacting with the natural ligand. In addition, the results of the ADP-induced platelet aggregation experiment indicated that these isolates may block platelet activation by inhibiting $\mathrm{P} 2 \mathrm{Y}_{12} \mathrm{R}$.

More recently, the genetic screening of natural products has been developed for an $\mathrm{FeCl}_{3}$-induced thrombosis model in zebrafish in vivo, which overcomes the limitations of the mouse model. ${ }^{27,28}$ Prior to investigating the antithrombotic effect, we determined the viability of zebrafish embryos pretreated with increasing doses of isolates ( 50 and $150 \mu \mathrm{g} \mathrm{mL}^{-1}$ ) for $48 \mathrm{~h}$. The results obtained showed that compounds 1-4, 8, 11 and 15 did not influence the embryo viability in cultured zebrafishes up to

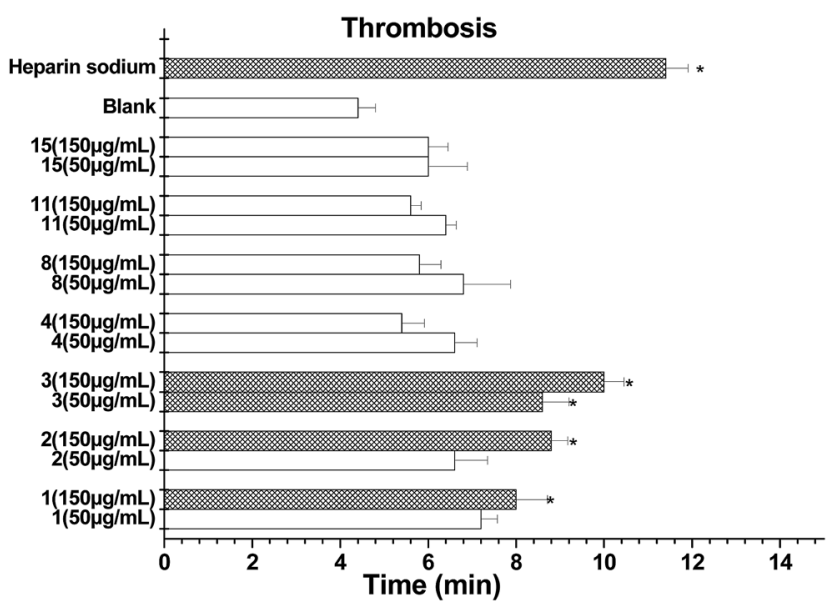

Fig. 7 Antithrombotic activity of compounds 1-4, 8, 11 and 15 on zebrafish.
$150 \mu \mathrm{g} \mathrm{mL} \mathrm{m}^{-1}$. Next, different doses of each compound were investigated using this thrombosis model. Compounds 1-3 clearly prolonged the time to form a thrombus in the tested zebrafish (Fig. 7). Among them, the thrombosis time of 3 was around or over 2.2-fold that of the model control and was the most potential.

\section{Experimental}

\section{General experimental procedures}

Optical rotations were obtained using an Autopol IV automatic polarimeter (Rudolph Research Analytical). UV spectra were recorded on a Shimadzu double-beam 210A spectrometer. The ECD spectra were measured with a BioLogic MOS-450 spectropolarimeter. NMR spectra were recorded on a Bruker ARX400 and 600 spectrometer with TMS as internal standard in dimethyl sulfoxide- $d_{6}$ (DMSO- $d_{6}$ ). Mass spectra were determined on a HRESI-MS: MicroTOF spectrometer (Bruker Daltonics, CA). TLC silica gel (GF254), silica gel (200-300 mesh) and polyamide (200-400 mesh) were purchased from Qingdao Marine Chemical Co., China. Reversed-phase $\mathrm{C}_{18}$ silica gel (ODS 70-80 $\mu \mathrm{m}$ Merck, Germany). Solvents were of industrial purity and distilled prior to use.

\section{Plant material and animals}

The leaves of Crataegus pinnatifida (Rosaceae) were gathered from Liaoning in November 2015, and authenticated by pharmacognosy Prof. Lu Jin-Cai. A voucher specimen (HY151108) is kept in the Nature Products Laboratory of Shenyang Pharmaceutical University, Shenyang, China.

Sprague-Dawley (SD) rats (8 weeks, 220-240 g) were obtained from Liao Ning Chang Sheng Biotechnology Co., Ltd. They were housed in a conventional animal facility with free access to food and water in a temperature and relative humidity controlled environment under a $12 \mathrm{~h}$ light/dark schedule. Adult zebrafish $(\mathrm{AB})$ were obtained from Biology Institute of Shandong Academy of Sciences (Jinan, China), and fish were maintained with a 14/ $10 \mathrm{~h}$ light/dark cycle. Zebrafish were fed with Tetramin granulated food and live brine shrimps (Artemia nauplii). Embryos were obtained from natural spawning, which was induced in the next morning after mating, and were placed in the embryos medium (5.0 mM NaCl, $0.17 \mathrm{mM} \mathrm{KCl}, 0.4 \mathrm{mM} \mathrm{CaCl}_{2}, 0.16 \mathrm{mM}$ $\mathrm{MgSO}_{4}$ ) under $28{ }^{\circ} \mathrm{C}$, to feed them for three days post fertilization (dpf). All animal procedures were carried out according to the Regulations of Experimental Animal Administration issued by State Committee of Science and Technology of China, and approved by the institutional ethical committee (IEC) of Shenyang Pharmaceutical University.

\section{Extraction and isolation}

Exhaustive extraction of C. pinnatifida leaves (15 kg) with $50 \%$ ethanol (total $270 \mathrm{~L}$ ) followed by reflux two times, which was prepared according to Pharmacopoeia of People's Republic of China (Yixintong medicinal preparations in page 396-397). The concentrated crude extract $(2.0 \mathrm{~kg})$ was separated by macroporous resin $(20 \mathrm{~kg})$ with $\mathrm{EtOH} / \mathrm{H}_{2} \mathrm{O}(\mathrm{v} / \mathrm{v}=0: 100,10: 90$, 
$60: 40,95: 5)$. The $60 \%$ ethanol fraction (280 g) was further separated by polyamide ( $2 \mathrm{~kg}$ ) column chromatography (EtOH/ $\mathrm{H}_{2} \mathrm{O} 20: 70,40: 60$, $60: 40$, $\left.95: 5\right)$ to provide 4 fractions (Frs. a-d). Fr. a (26 g) was subjected to silica gel (200 g) chromatography eluting with a $\mathrm{CH}_{2} \mathrm{Cl}_{2}-\mathrm{EtOH}(\mathrm{v} / \mathrm{v}=30: 1,15: 1$, $10: 1,8: 1$ ) and further purified by ODS (50 g) column chromatography with EtOH $: \mathrm{H}_{2} \mathrm{O}(3: 4)$ to yield compounds 8 (12 mg), 10 (23 mg), 13 (23 mg), 14 (9 mg) and 15 (15 mg) which were further purified by preparative HPLC. And the same method was employed to obtain compounds 3 (27 mg), 4 (11 mg) and 6 (22 mg), 9 (16 mg), 11 (53 mg) and 12 (45 mg) from the next fraction (Frs. b, $35 \mathrm{~g}$ ). Compounds 1 ( $9 \mathrm{mg}), 2$ (12 mg), 5 (28 mg) and 7 (19 mg) from Frs. c, (23 g).

Norhawthornoid A (1). Colorless oil; $[\alpha]_{20}^{\mathrm{D}}-3.5,(c \quad 0.15$, $\mathrm{MeOH}) ; \mathrm{UV}(\mathrm{MeOH}) \lambda_{\max }(\log \varepsilon) 208$ (2.21) nm; ECD $(\mathrm{MeOH}) \lambda$ $(\Delta \varepsilon) 209(-39.50) \mathrm{nm}$; see Table 1 for ${ }^{1} \mathrm{H}$ NMR, ${ }^{13} \mathrm{C}$ NMR; HRESIMS $m / z: 483.2582[\mathrm{M}+\mathrm{H}]^{+}$(calcd $\mathrm{C}_{25} \mathrm{H}_{39} \mathrm{O}_{9}$ 483.2589).

Norhawthornoid B (2). Colorless oil; $[\alpha]_{20}^{\mathrm{D}}-8.5,(c \quad 0.12$, $\mathrm{MeOH}) ; \mathrm{UV}(\mathrm{MeOH}) \lambda_{\max }(\log \varepsilon) 228$ (2.21) nm; ECD $(\mathrm{MeOH}) \lambda$ $(\Delta \varepsilon) 230(-9.80) \mathrm{nm}$; see Table 1 for ${ }^{1} \mathrm{H}$ NMR, ${ }^{13} \mathrm{C}$ NMR; HRESIMS $m / z: 471.2588[\mathrm{M}+\mathrm{H}]^{+}$(calcd $\mathrm{C}_{24} \mathrm{H}_{38} \mathrm{O}_{9} 471.2589$ ).

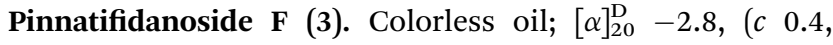
$\mathrm{MeOH})$; see Table 2 for ${ }^{1} \mathrm{H}$ NMR, ${ }^{13} \mathrm{C}$ NMR; HRESIMS $m / z$ : 401.2536 [M + H $]^{+}$(calcd $\mathrm{C}_{21} \mathrm{H}_{37} \mathrm{O}_{7}$ 401.2534).

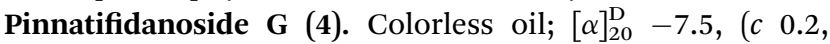
$\mathrm{MeOH})$; see Table 2 for ${ }^{1} \mathrm{H}$ NMR, ${ }^{13} \mathrm{C}$ NMR; HRESIMS $m / z$ : 419.2636 [M + H] $]^{+}$(calcd $\mathrm{C}_{21} \mathrm{H}_{39} \mathrm{O}_{8}$ 419.2639).

Characteristic data of compounds 5-15 see ESI-E.2. $\dagger$

\section{Acid hydrolysis of 1-4}

Compounds 1-4 (each $2.0 \mathrm{mg}$ ) were individually hydrolyzed by $6 \% \mathrm{HCl}(1.0 \mathrm{~mL})$ under reflux for $2 \mathrm{~h}$. The reaction mixtures were extracted with $\mathrm{CH}_{2} \mathrm{Cl}_{2}$, and the organic layers evaporated under reduced pressure to yield $1^{\prime}(0.2 \mathrm{mg}), 2^{\prime}(0.5 \mathrm{mg}), 3^{\prime}$ $(0.7 \mathrm{mg})$, and $\mathbf{4}^{\prime}(0.8 \mathrm{mg})$. D-Glucose was obtained from the aqueous layers of 1-4 and identified by HPLC confirmation (Shodex Asahipak NH2P-50 4E, $250 \times 4.6 \mathrm{~mm}$ no. N1490155; flow rate $1.0 \mathrm{~mL} \mathrm{~min}^{-1}$; eluent $\mathrm{CH}_{3} \mathrm{CN} / \mathrm{H}_{2} \mathrm{O}, 3: 1$ ) with the authentic sample using optical rotation detector (Jasco OR-4090).

\section{Preparation of the $(R)$ - and $(S)$-MTPA esters of $4^{\prime}$}

To a solution of $4^{\prime}(1.0 \mathrm{mg})$ in dry pyridine $(200 \mu \mathrm{L})$ was added $(S)$-MTPA chloride $(20 \mu \mathrm{L})$. The mixture was allowed to stand under $\mathrm{N}_{2}$ at room temperature for $2 \mathrm{~h}$. The solution was concentrated under vacuum to afford a residue, which was subjected to semipreparative HPLC with an RP-C $_{18}$ column afforded the $(S)$-MTPA esters of $\mathbf{4}^{\prime}$. The $(R)$-MTPA ester of $\mathbf{4}^{\prime}$ was prepared with $(R)$-MTPA chloride and was purified in the same manner. $4^{\prime} S$ : from $1.0 \mathrm{mg}$ of $\mathbf{4}^{\prime}$ was obtained $0.3 \mathrm{mg}$ of $(S)$-MTPA ester. $4^{\prime} R$ : from $1.0 \mathrm{mg}$ of $\mathbf{4}^{\prime}$ was obtained $0.2 \mathrm{mg}$ of $(R)$-MTPA ester.

\section{$\mathrm{Rh}_{2}\left(\mathrm{OCOCF}_{3}\right)_{4}$-induced ECD experiment of $\mathbf{1}^{\prime}$ and 5}

Compound $\mathbf{1}^{\prime}$ and $5(0.5 \mathrm{mg})$ were dissolved in a dry solution of $\left[\mathrm{Rh}_{2}\left(\mathrm{OCOCF}_{3}\right)_{4}\right]$ complex $(1.0 \mathrm{mg})$ in $\mathrm{CDCl}_{3}(700 \mu \mathrm{L})$. The first ECD spectrum was recorded immediately after mixing, and its time evolution was monitored until stationary (10-15 min after mixing). The inherent ECD was subtracted. The observed sign of the $\mathrm{E}$ band at about $350 \mathrm{~nm}$ in the induced ECD spectrum was correlated to the absolute configuration of the C-8 of $\mathbf{1}^{\prime}$ (secondary alcohol moiety), as well as the C-3 of 5 (tertiary alcohol moiety). ${ }^{29}$

\section{Computational methods}

Quantum chemical ECD calculation. Initial structures were constructed based on information of NOESY correlations, and conformational analysis was performed by using the MMFF molecular mechanics force field. Further optimization of the structures in methanol was performed using the Gaussian 09 program. ${ }^{30}$ The optimized structures were shown in ESI-Tables 1 and $2 . \dagger$ Optimization was confirmed by computation of frequency. Conformational distribution of the optimized structures was investigated at B3LYP/6-31G (d) and suggested the major conformers $(>98 \%)$. Energies of the geometric conformations in $\mathrm{MeOH}$ were calculated at the B3LYP/6-311+G (d) level. Solvent effects were considered by using the conductor-like polarizable continuum model (CPCM). The hybrid B3LYP functionals were choosed to run the TDDFT calculations, solving for 30 states for per molecule of $\mathbf{1}^{\prime}$ and $\mathbf{2}^{\prime}$. The ECD spectra were generated using the program SpecDis with a half-bandwidth of $0.30 \mathrm{eV}$ (for $\mathbf{1}^{\prime}$ and $\mathbf{2}^{\prime}$ ). After hypsochromic-shifting $8 \mathrm{~nm}$ (for $\mathbf{1}^{\prime}$ ) and $-20 \mathrm{~nm}$ (for $\mathbf{2}^{\prime}$ ) by UV correction, in the $190-400 \mathrm{~nm}$ region, the theoretically calculated ECD spectra of $\mathbf{1}^{\prime} \mathbf{a}$ and $\mathbf{2}^{\prime} \mathbf{b}$ were in good agreement with the experimental ECD spectra of $\mathbf{1}^{\prime}$ and $\mathbf{2}^{\prime}$ (Fig. 3 ).

${ }^{13} \mathrm{C}$ NMR calculation section (ESI-Tables 3-5 $\dagger$ ). After optimization of the major conformers $(>98 \%)$ was performed using the Gaussian 09 program at B3LYP/6-31G(d) level. Computed chemical shifts reported in this study were determined using the GIAO method in Gaussian 09 at the B3LYP/6-311+G(d) level of theory. ${ }^{30}$ The scaled calculated ${ }^{13} \mathrm{C}$ NMR chemical shifts were obtained from the following: $\delta_{\text {scal.calc. }}=\left(\delta_{\text {calc. }}-\right.$ intercept $) /$ slope. ${ }^{31}$ The results were evaluated in terms of $R^{2}$, MaxDev and AveDev. Among them, $R^{2}$ is its coefficient of determination. MaxDev is the maximum absolute deviation with respect to the experimental chemical shifts $\delta_{\text {exp }}$. AveDev is the average absolute deviation, computed as $(1 / n) \sum_{i=1}^{n}\left|\delta_{\text {scal.calc. }}-\delta_{\text {exp. }}\right|$.

Optical rotations (ORs) calculation section (ESI-Table 6†). A conformational search using the Molecular Merck force field (MMFF) led to the identification of the major conformers $(>98 \%)$, which was performed using the Gaussian 09 program at B3LYP/6-31G(d) level. ${ }^{30}$ Geometry optimization followed by OR calculations at D-sodium line radiation (wavelength of $589 \mathrm{~nm}$ ) in $\mathrm{MeOH}$ (CPCM) using the B3LYP functional and the 6$311+\mathrm{G}(\mathrm{d})$ basis set for DFT. Final calculated ORs were obtained as the result of the Boltzmann-weighted average.

\section{Evaluation of antiplatelet activity in rat PRP}

Evaluation of the antiplatelet aggregation activities of pure compounds 1-15, positive control (aspirin) and blank (normal 
saline) were performed using an antiplatelet aggregation method. ${ }^{25}$ SD rats weighing 200-240 g were lightly anesthetized with diethyl ether. A volume of $8-10 \mathrm{~mL}$ of blood was collected from the abdominal aorta into a syringe containing $3.8 \%$ sodium citrate. The ratio of blood to $3.8 \%$ sodium citrate was adjusted to $1: 9 \mathrm{v} / \mathrm{v}$ and then centrifuged at $150 \mathrm{~g}$ for $10 \mathrm{~min}$ to obtain platelet-rich plasma (PRP) used for the aggregation study. PRP $(2 \times 108$ platelets per $\mathrm{mL})$ was prewarmed at $37{ }^{\circ} \mathrm{C}$ for $2 \mathrm{~min}$. The isolates 1-15 dissolved respectively in 5\% dimethylsulfoxide at a concentration of $6.25 \mathrm{mg} \mathrm{mL}^{-1}(10 \mu \mathrm{L})$ were added to the diluted PRP $(230 \mu \mathrm{L})$ before the addition of the platelet aggregation agent. PRP aggregation was induced by $10 \mu \mathrm{L} \operatorname{ADP}(62.5 \mu \mathrm{M})$. The final concentration of all samples was $0.25 \mathrm{mg} \mathrm{mL} \mathrm{mL}^{-1}$. In positive and blank control experiments, normal saline and aspirin were added instead of the isolates. From each series of experiments, the inhibitors were tested in at least three times, and the extent of antiplatelet aggregation was measured by the percentage inhibition of the control value. The results obtained are shown in Table 3, ESI-Fig. $8 . \dagger$

\section{Antithrombotic assay using a zebrafish system}

The arachidonic acid $\left(\mathrm{FeCl}_{3}\right)$ was used to induce larval zebrafish thrombus as model group. Three dpf (days post fertilization) AB-type zebrafish embryos were placed into 24 well plates with ten ones per well. Then the embryos were exposed to select positive control (20 $\mathrm{U} \mathrm{mL}^{-1}$ heparin sodium) and test sample solutions at final concentrations $\left(50,150 \mu \mathrm{g} \mathrm{mL}{ }^{-1}\right)$ in $0.2 \%$ DMSO for $48 \mathrm{~h}$ until five dpf. The negative control group was the solvent group, which not only represented the back ground value of the test group, but also made sure that the cardiac red blood cells of larval zebra fish were normal. The larval zebrafish were treatment with $60 \mu \mathrm{g} \mathrm{mL}^{-1}$ of $\mathrm{FeCl}_{3}$, and the time was recorded until a thrombus was observed in the venous system. Meanwhile, it also needed to be observed if there was the presence of embryonic death or deformity. The thrombosis time of the heparin sodium was normalised to $100 \%$ and the results were expressed as a percentage of the control (Fig. 7).

\section{Molecular modeling (docking) studies}

Docking of AZD1283 and compound 3 into the $\mathrm{P}_{2} \mathrm{Y}_{12}$ was performed with Molegro virtual docker (Molegro). The X-ray crystal structure of the $\mathrm{P} 2 \mathrm{Y}$ receptor $\mathrm{P}^{2} \mathrm{Y}_{12}$ (PDB code 4PXZ) was obtained from the RCSB Protein Data Bank. The co-crystal ligand AZD1283 was extracted to define the binding site in docking. The structure of compound $\mathbf{3}$ was constructed and energy minimized for 1000 iterations reaching a convergence of $0.01 \mathrm{kcal} \mathrm{mol}^{-1} \AA^{-1}$. The docking experiments on $\mathrm{P}_{2} \mathrm{Y}_{12}$ were carried out by superimposing the minimized ligand into the receptor. Ten runs were performed and five poses returned. All the other docking parameters were set as default. The pose for which the biotin entity of AZD1283 and 3 binds to $\mathrm{P}_{2} \mathrm{Y}_{12}$ receptor in a similar way as observed in the original ligandenzyme complex was exported and examined with Discovery Studio Visualizer 4.0 (Accelrys).

\section{Conclusions}

In summary, our current study describes the discovery of two uncommon norditerpenoids (1-2) and 13 sesquiterpenoids (315). The compounds 1 and 2 represent the first examples of diterpenoids obtained from Crataegus genus. The new compounds 1-3 exhibited exceptionally potent antithrombotic activities in vitro/vivo. The most potent one, pinnatifidanoside $\mathrm{F}$ (3), is about 2.2-fold more potent compared with the model control in the zebrafish model for thrombosis (in vivo). It is interesting to study the kinds of antithrombotic ingredients present in the title plant. Particularly, these terpenoids could play an important role on their own or in good synergy with flavonoids. This need to be examined in future research studies.

\section{Conflicts of interest}

There are no conflicts to declare.

\section{Acknowledgements}

Financial support from the Project of National Natural Science Foundation of P. R. China (81302661), Innovation Team (LT2015027) of Liaoning of P. R. China, and Foundation (L2015419) from the Project of Education Department of Liaoning province of P. R. China are gratefully acknowledged. The authors thank Molegro ApS for kindly providing us with a free evaluation of their software packages. The authors also thank Li W. and Sha Y. of Shenyang Pharmaceutical University for recording NMR spectra.

\section{Notes and references}

1 N. L. Smith, L. B. Harrington, M. Blondon, K. L. Wiggins, J. S. Floyd, C. M. Sitlani, B. McKnight, E. B. Larson, F. R. Rosendaal, S. R. Heckbert and B. M. Psaty, J. Thromb. Haemostasis, 2016, 7, 1384.

2 E. Fuentes and I. Palomo, J. Funct. Foods, 2014, 6, 73.

3 Y. N. Shi, Y. M. Shi, L. Yang, X. C. Li, Z. H. Zhao, Y. Qu, H. T. Zhu, D. Wang, R. R. Cheng, C. R. Yang, M. Xu and Y. J. Zhang, J. Ethnopharmacol., 2015, 162, 87.

4 J. X. Qiao, T. C. Wang, S. Hiebert, C. H. Hu, W. A. Schumacher, S. A. Spronk, C. G. Clark, Y. Han, J. Hua, L. A. Price, H. Shen, S. A. Chacko, G. Everlof, J. S. Bostwick, T. E. Steinbacher, Y. X. Li, C. S. Huang, D. A. Seiffert, R. Rehfuss, R. R. Wexler and P. Y. S. Lam, ChemMedChem, 2014, 9, 2327.

5 D. J. Newman and G. M. Cragg, J. Nat. Prod., 2016, 79, 629. 6 R. Guo, M. H. Pittler and E. Ernst, Cochrane Database Syst. Rev., 2008, 1, 1.

7 P. Z. Liu, H. K. Kallio, D. G. Lü, C. S. Zhou, S. Ou and B. J. Yang, J. Agric. Food Chem., 2010, 58, 1012.

8 M. Luo, J. Y. Hu, Z. Y. Song, J. Jiao, F. S. Mu, X. Ruan, Q. Y. Gai, Q. Qiao, Y. G. Zu and Y. J. Fu, RSC Adv., 2015, 5, 67532.

9 H. F. Pan, X. Wang, Y. L. Du, Y. R. Li, S. N. Zhao and W. D. Pan, Anal. Methods, 2014, 6, 7475. 
10 B. M. Fraga, Nat. Prod. Rep., 2012, 29, 1334.

11 J. E. Edwards, P. N. Brown, N. Talent, T. A. Dickinson and P. R. Shipley, Phytochemistry, 2012, 79, 5.

12 S. J. Song, L. Z. Li, P. Y. Gao, Y. Peng, J. Y. Yang and C. F. Wu, Food Chem., 2011, 129, 933.

13 P. Y. Gao, L. Z. Li, Y. Peng, F. F. Li, C. Niu, X. X. Huang, M. Ming and S. J. Song, Biochem. Syst. Ecol., 2010, 38, 988.

14 L. Z. Li, P. Y. Gao, S. J. Song, Y. Q. Yuan, C. T. Liu, X. X. Huang and Q. B. Liu, J. Funct. Foods, 2015, 12, 237.

15 J. H. Shin, Y. W. Seo and K. W. Cho, J. Org. Chem., 1999, 64, 1853.

16 Y. Tang, Y. B. Xue, G. Du, J. P. Wang, J. J. Liu, B. Sun, X. N. Li, G. M. Yao, Z. W. Luo and Y. H. Zhang, Angew. Chem., Int. Ed., 2016, 55, 4069.

17 G. Q. Zhan, J. J. Liu, J. F. Zhou, B. Sun, H. J. Akber Aisa and G. M. Yao, Eur. J. Med. Chem., 2017, 127, 771.

18 J. Frelek and W. J. Szczepek, Tetrahedron: Asymmetry, 1999, 10, 1507.

19 M. T. Liu, S. Lin, M. L. Gan, M. H. Chen, L. Li, S. J. Wang, J. C. Zi, X. N. Fan, Y. Liu, Y. K. Si, Y. C. Yang, X. G. Chen and J. G. Shi, Org. Lett., 2012, 14, 1004.

20 L. W. Tian, Y. J. Feng, T. D. Tran, Y. Shimizu, T. Pfeifer, P. I. Forster and R. J. Quinn, J. Nat. Prod., 2015, 78, 1756.

21 D. P. Curran, Q. S. Zhang, H. J. Lu and V. Gudipati, J. Am. Chem. Soc., 2006, 128, 9943.

22 M. Diaz, J. Jaballas, J. Arias, H. Lee and T. Onak, J. Am. Chem. Soc., 1996, 118, 4405.

23 G. Barone, D. Duca, A. Silvestri, L. Gomez-Paloma, R. Riccio and G. Bifulco, Chem.-Eur. J., 2002, 8, 3240.

24 P. Jagadeeswaran, M. Gregory, K. Day, M. Cykowski and B. Thattaliyath, J. Thromb. Haemostasis, 2005, 3, 46.

25 G. H. Tang, G. H. Jiang, S. Z. Wang and L. F. Zheng, Chin. J. Pharmacol. Toxicol., 2001, 15, 317.
26 J. Zhang, K. Zhang, Z. G. Gao, S. Paoletta, D. Zhang, G. W. Han, T. Li, L. Ma, W. Zhang, C. E. Muller, H. Yang, H. Jiang, V. Cherezov, V. Katritch, K. A. Jacobson, R. C. Stevens, B. Wu and Q. Zhao, Nature, 2014, 509, 119.

27 K. D. Kurz, B. W. Main and G. E. Sandusky, Thromb. Res., 1990, 60, 269.

28 M. R. Lang, G. Gihr, M. P. Gawaz and I. I. Müller, J. Thromb. Haemostasis, 2010, 8, 1159.

29 L. Xiong, C. G. Zhu, Y. R. Li, Y. Tian, S. Lin, S. P. Yuan, J. F. Hu, Q. Hou, N. H. Chen, Y. H. Yang and J. P. Shi, J. Nat. Prod., 2011, 74, 1188.

30 M. J. Frisch, G. W. Trucks, H. B. Schlegel, G. E. Scuseria, M. A. Robb, J. R. Cheeseman, G. Scalmani, V. Barone, B. Mennucci, G. A. Petersson, H. Nakatsuji, M. Caricato, X. Li, H. P. Hratchian, A. F. Izmaylov, J. Bloino, G. Zheng, J. L. Sonnenberg, M. Hada, M. Ehara, K. Toyota, R. Fukuda, J. Hasegawa, M. Ishida, T. Nakajima, Y. Honda, O. Kitao, H. Nakai, T. Vreven, J. A. Montgomery, J. E. Peralta, F. Ogliaro, M. Bearpark, J. J. Heyd, E. Brothers, K. N. Kudin, V. N. Staroverov, T. Keith, R. Kobayashi, J. Normand, K. Raghavachari, A. Rendell, J. C. Burant, S. S. Iyengar, J. Tomasi, M. Cossi, N. Rega, J. M. Millam, M. Klene, J. E. Knox, J. B. Cross, V. Bakken, C. Adamo, J. Jaramillo, R. Gomperts, R. E. Stratmann, O. Yazyev, A. J. Austin, R. Cammi, C. Pomelli, J. W. Ochterski, R. L. Martin, K. Morokuma, V. G. Zakrzewski, G. A. Voth, P. Salvador, J. J. Dannenberg, S. Dapprich, A. D. Daniels, O. Farkas, J. B. Foresman, J. V. Ortiz, J. Cioslowski and D. J. Fox, Gaussian 09, Gaussian, Inc., C. T. Wallingford, 2010.

31 G. Barone, L. Gomez-Paloma, D. Duca, A. Silvestri, R. Riccio and G. Bifulco, Chem.-Eur. J., 2002, 8, 3233. 